\title{
STATE STATUTES GOVERNING THE CANCELLATION OF AUTOMOBILE INSURANCE
}

Recent criticism of automobile liability insurance practices, in particular the cancellation of policies, led to the enactment of federal legislation authorizing the Secretary of Transportation to conduct a two year comprehensive study of that industry. Such a study may well recommend federal regulation of automobile insurance in a sharp break with the tradition of state regulation. The states, however, have not been entirely unresponsive and several have recently enacted restrictive statutes aimed at correcting the problems raised by cancellation practices. The present comment is a survey, grouping, and analysis of the major types of state legislation addressing the problem of cancellation and presents recommended steps which could be taken to correct the weaknesses of such statutes.

$\mathrm{T}$

HE EMERGENCE of automobile accidents as a national safety problem of the first magnitude has been paralleled by the growth of state regulation of automobile insurance. ${ }^{\prime}$ Such regulation, operating within the limits of the fault liability system, ${ }^{2}$ has been designed primarily to provide a solvent defendant from whom an injured victim might seek compensation. Thus, Financial Responsibility and Compulsory Insurance Laws, the typical means of assuring solvency, envisage insurance covering the driver who is likely to cause an accident. ${ }^{3}$ The obligations placed upon insurers by the legislation and the economics of automobile insurance force insurance companies into competition to insure the greatest number of drivers who present the least risk to the insurer. ${ }^{4}$ As a result of such pressures, insurers have perhaps been more ready to cancel or

\footnotetext{
' For an early depiction of the scope of the problem and legislative responses, see $\mathrm{C}$. SUNDERLIN, AUTOMOBILE INSURANCE $\S \S 1-13$ (1929).

2 See R. Keeton \& J. O'Connell, Basic Protection for the Traffic Victim (1965).

${ }^{3}$ See notes 24 \& 25 infra and accompanying text.

- See Hearings on H.J. Res. 958 Before the Subcomm. on Commerce and Finance of the House Comm. on Interstate and Foreign Commerce, 90th Cong., 2d Sess. 31-32, 37 (1968) [hereinafter cited as Hearings]; CRISIS in CAR Insurance 232, 255, 262, 266 (R. Keeton, J. O'Connell \& J. McCord ed. 1968).
} 
fail to renew a policy than would be the case absent such legislation. Regardless of the validity of this idea, popular attitudes apparently have developed which generally accept such allegations as well as the assertion that state regulation has been unable to deal with the problem. ${ }^{5}$

Traditionally, the states had regulated the insurance business and were thought to possess sole competence in the area ${ }^{6}$ until 1944, when federal regulation was upheld in the Southeastern Underwriters case. ${ }^{7}$ However, the McCarran-Ferguson Act, ${ }^{8}$ passed in response to that decision, ${ }^{9}$ adopted the philosophy of state regulation and prevented any federal encroachment into the field of insurance regulation by legislation other than that specifically intended to do so..$^{10}$ The recent upsurge of criticism of automobile liability insurance, however, seems to threaten this philosophy. Apparently in response to this wave of criticism," Congress enacted legislation in May, 1968 to authorize the Secretary of Transportation to conduct a comprehensive investigation of the

s See generally TIME, July 19, 1968 at 65-66; U.S. NEws \& WORLD ReporT, Feb. 26, 1968, at 102-14. See also 1966-2 Proceedings of the National association of INSURANCE COMMISSIONERS 510-513.

- Paul v. Virginia, 75 U.S. (8 Wall.) 168 (1868). An 1866 Act of the Virginia Legislature provided that foreign insurance eompanies must obtain a license and deposit a bond in order to conduct business within the State. A subsequent act provided that no person may act as an agent for an unlicensed foreign insurer. Samuel Paul undertook to act as an insurance agent in violation of these acts and was fined in State court.

Paul argued that the Virginia statute was state regulation of interstate commerce which encroached upon an area of exclusive federal jurisdiction under the commerce clause. 75 U.S. (8 Wall.) at 173-74. The Supreme Court, per Field, J., held that insurance contracts were not interstate transactions but simply contracts which, becoming effective only upon delivery within the state, were solely local transactions and subject to local, not federal, law. 75 U.S. (8 Wall.) at 183-85. Cf. New York Life Ins. Co. v. Cravens, 178 U.S. 389 (1900); Metropolitan Cas. Ins. Co. v. Brownell, 68 F.2d 481, 482 (7th Cir. 1934).

7 United States v. Southeastern Underwriters, 322 U.S. 533 (1944).

\$15 U.S.C. $\S \S 1011-1015$ (1964).

- See H.R. Rep. No. 143, 79th Cong., lst Sess. (1945); 1945 U.S. Code Cong. Serv. 670 (now U.S. CODE CONG. \& AD. NEWS).

10 "No Act of Congress shall be construed to invalidate, impair, or supersede any law enacted by any State for the purpose of regulating the business of insurance . . . unless such Act specifically relates to the business of insurance . . ." 15 U.S.C. $\S 1012(\mathrm{~b})$ (1964) (emphasis added).

"See generally Hearings, supra note 4. See also note 5 supra. A good part of the criticism of present insurance practices is somewhat unfair in failing to note that these practices are the result of the fault liability system which places the insurer and the injured accident victim in the role of adversaries. 
existing compensation system for motor vehicle accident losses. ${ }^{12}$ Legislative history makes it clear that one of the primary concerns of the two-year study will be the automobile liability insurance business. ${ }^{13}$ The hearings indicate that Congress is receptive to the idea of bringing the insurance industry under federal regulation, despite the dictates of the 1944 McCarran-Ferguson Act. ${ }^{14}$

Testimony before a Subcommittee of the House Committee on Interstate and Foreign Commerce revealed concern with virtually every phase of automobile insurance. The greatest concern was evidenced in regard to cancellation practices prevailing in the industry, numerous congressmen indicating that they commonly received complaints about arbitrary cancellations..$^{15}$ Closely allied concerns were blanket area cancellations and possible discriminatory action by insurers against elderly, young and minority group drivers. ${ }^{16}$

Although Congress chose to await the results of the study rather than to legislate in 1968 , some legislative response to the study and the recommendations of the Secretary of Transportation is to be anticipated in 1970. However, it should be noted that the states have not been unaware of the problems of cancellation. Recent legislative activity indicates state awareness of the problems and an effort to control them. ${ }^{17}$ While testimony before the Subcommittee revealed considerable support for immediate federal regulation of the area, ${ }^{18}$ it would seem that an examination of

1282 Stat. 126 (1968) (1968 U.S. CODE CONG. \& AD. NEwS 154).

${ }^{13}$ See generally. Hearings. supra note 4: 1968 U.S. CODE CONG. \& AD. News 1937 et seq.

1415 U.S.C. $\$ \S 1011-1015$ (1964); see notes 7-8 supra and accompanying text.

${ }^{13}$ Hearings, supra note 4 , at $11,29,68,69$.

${ }^{18}$ Such problems are subject to treatment within the broader context of cancellations in general and will not be treated specifically herein. These problems have been recognized by the states and some remedial action has been taken. See, e.g., N.C. GEN. STat. $\$ 20-310.2$ (Supp. 1967), which provides that insurers may not discriminate against aged people. See also 1967-1 Procefdings of the National Association of Insurance Commissioners 179-80.

"See, e.g., Cal. Ins. Code $\$ \S 65 I-53,660-69$ (West Supp. 1968); Kan. Stat. AnN. $\S 40-276$ el seq. (Supp. 1968); N.Y. INs. LaW § 167a (McKinney Supp. 1968); WASH. Rev. CODE ANN. \& 48.18.294 (Supp. 1968).

'See Hearings, supra note 4, at II (Hon. George M. Rhodes, Congressman, Pa.), 13 (Hon. Lconard Farbstein, Congressman, N.Y.), 34-38 (Kenneth Meiklejohn, Legislative Representative, AFL-CIO), 70 (Hon. Joshua Eilberg, Congressman, Pa.), 7 I (Hon. George P. Miller, Congressman, Cal.), 75 (Hon. William T. Cahill, Congressman, N.J.). See also 1968 U.S. Code Cong. \& AD. News 1949-50 (Hon. Riehard Ottinger, Congressman, N.Y.). 
present state regulatory efforts should be a prerequisite to changing the long-standing philosophy of state regulation. Much of the state legislative activity occurred only recently, ${ }^{19}$ and its effects have not yet been considered by the courts, nor are they likely to be so considered before the termination of the authorized study. An inquiry into the status of state regulatory efforts is therefore worthwhile, as a benchmark for possible future federal legislation. This comment will survey, classify and analyze the various state statutory approaches to the problem of automobile liability insurance cancellation. Because cancellation by the insurer is the primary concern of critics, congressmen, and presumably insured parties, ${ }^{20}$ the statutes are examined from that standpoint exclusively.

\section{Financial Responsibility Statutes}

Although legislation recently enacted in some states undertakes to restrict severely the ability of insurers to cancel automobile liability insurance policies, ${ }^{21}$ many states have no restrictions upon the insurer's ability to cancel, and the matter of cancellation is regarded as one of contract between the parties.22 Although there is some degree of official concern in these states with the status of existing liability insurance policies, such concern is usually manifested within the confines of the local Safety or Financial Responsibility Law and is directed not at preventing arbitrary cancellations but toward insuring that traffic accident victims will have a solvent defendant to sue. ${ }^{23}$

19 See note 17 supra.

${ }^{20}$ At least one state has determined that the public interest requires insured policy-holders to meet some strict notice requirements before insured-initiated cancellation becomes effective. Mass. Gen. Laws ANN. ch. 175, § 113A (1959).

${ }^{21}$ See note 17 supra and accompanying text.

z See, e.g., Ala. CODE tit. 36, $\S 74(42)-(83)$ (1958); Alaska Stat. $\S 28.20 .010-640$ (1962); Colo. Rev. Stat. ANN. $\S 13-7-1$ to 39 (1963); Conn. Gen. Stat. Rev. $\$ 14-113$ to 133 (1958); Hawall Rev. LaWs $\S \S 80-126$ (1955); IDAho Code ANN. $\S \S 49-1501$ to 1540 (1967); lowa Code $\S \S 321$ A.I -.39 (1966); Ky. Rev. STAT. $\S \S 187.290-.990$ (1962); Mo. Rev. Stat. $\S \S 303.010-.370$ (1959); Mont. Rev. Codes ANN. $\S \S 53-418$ to 458 (1961); Ohio Rev. Code ANn. $§ \$ 4509.1$-99 (Page 1965); Okla. Stat. Ann. tit. 47, $\$ \S 7-101$ to 505 (1962); TeX. Rev. Civ. Stat. ANN. art. 6701(h) (1960).

2 See, e.g., Alaska Stat. \& 28.20.010 (1962); Conn. Gen. Stat. Rev. § 14-112 (1958); Mo. Rev. Stat. § 303.070 (1959); N.C. Gen. Stat. § 20.279.1(11) (Supp. 1967). Sce generally Legislation, $A$ Survey of Financial Responsibility Laws and Compensation of Traffic Victims: A Proposal for Reform, 21 VAND. L. REv. 1058 (1968). 
Typically, the Financial Responsibility statutes provide that certain classes of drivers, such as those convicted of driving while intoxicated ${ }^{24}$ must prove their ability to respond in damages to a liability judgment resulting from future negligent operation of a motor vehicle. ${ }^{25}$ This proof may take the form of either a bond or a liability insurance policy in a certain amount. ${ }^{26}$ Any such policy is certified according to the provisions of the statute and may not be cancelled without notifying the appropriate authority within a certain period before the effective date of cancellation. ${ }^{27}$

As these statutes provide for notice solely to the Commissioner of Motor Vehicles or other appropriate authority and not to the insured, the insurer is able to cancel for any reason it deems adequate, subject only to the terms of the contract ${ }^{28}$ and any statutory provisions extrinsic to the Financial Responsibility Law. ${ }^{29}$ It is commonly stated that insurance contracts may not be cancelled without the mutual consent of the parties unless they have provided for cancellation in the contract, ${ }^{30}$ but the typical contract

2 See, e.g., Kan. Stat. ANN. \$\$ 8-739, 8-254 (1964); MD. ANN. Code art. 66 1/2, \$§ 118, 104 (1957). Other classes include drivers who have been involved in accidents causing damages above a certain limit. See, e.g., Alaska Stat. \$ 28.20.050 (1962); lowa Code § 32IA.5 (1966); Ky. REV. STAT. § 187.330 (1962); N.C. GEN. STAT. § 20-279.5 (1965).

25 See, e.g.. Cal. Vehicle Code $\$ 16020$ (West 1960); N.C. GeN. STAT. \$ 20-279.1(11) (Supp. 1967); N.Y. VEh. \& TRAF. LaW $\S 335$ (McKinney Supp. 1968).

2 See, e.g.. Cal. Vehicle Code $\S \S 16023,16057,16059$ (West Supp. 1968); Fla. Stat. ANN. § 324.031 (1968); TeX. Rev. Civ. Stat. ANN. art. 6701(h), \& 18 (1960).

${ }^{7}$ See lowa CODE $\$ 321$ A.22 (1966) (10 days); N.Y. VeH. \& TRAF. LAw $\S 347$ (McKinney 1960) (10 days); N.C. Gen. Stat. $§ 20-279.22$ (1965) (20 days); Ohio Rev. Code ANN. $\S 4509.5$ (Page 1965) (10 days); Tex. Rev. Civ. STAt. ANN. art. 6701(h), $\$ 22$ (1960) (5 days).

2x Florida seems to be the single exception to this pattern, as its Financial Responsibility Law provides that the insurer is required to notify the insured as well as the Commissioner of Motor Vehicles in advance of cancellation. FLA. STAT. ANN. $\$ 324.181$ (1968). Other states have some rudimentary protection. Nebraska, for example, provides that liability insurance policies which are to be issued in that state must contain a clause governing cancellation in order to be approved for issuance by state authorities. NEB. REV. STAT. \& 44379 (1960). See also N.D. CENT. CODE § 26-02-32 (Supp. 1967). Such a provision seems clearly subject to the weaknesses noted in the text infra accompanying notes 30-34.

- For examples of states with both a Financial Responsibility Law and a statute regulating cancellations, see Kan. STAT. ANN. \$§ 8-722, 40-276 (1968); N.C. GEN. STAT. §§ 20-279.1, 20-310 (Supp. 1967).

so E.g., Wright v. Columbia Cas. Co., 137 F. Supp. 775 (S.D. W. Va.), affd, 235 F.2d 462 (4th Cir. 1956); Trans-America Ins. Co. v. Wilson, 262 Ala. 532, 80 So. 2d 253 (1955); Schnell v. United Hail lns. Co., 145 Neb. 768, 18 N.W.2d 112 (1955) (crop insurance); Slater v. Gen. Cas. Co., 344 Pä. 410, 25 A.2d 697 (1942). 
will generally prescribe some method of cancellation. Such clauses, as part of standard contracts, are not subject to bargaining between the parties, ${ }^{31}$ and the allocation of risk on the issue of cancellation is accomplished essentially by fiat of the insurer. Although strict construction of insurance contract terms may offer an opportunity for judicial mitigation of the rigors of a cancellation, ${ }^{32}$ the insured party must still depend on the interpretation of the wording of the contract clause by the court. Moreover, it would seem that the insurer could avoid the effect of any strict construction of a cancellation clause simply by redrafting the clause for future contracts. Thus, policyholders must essentially depend on the selfrestraint of the insurer ${ }^{33}$ Although insurers themselves are aware of the problem and have in some instances voluntarily restricted their own ability to cancel, ${ }^{34}$ the possibility of arbitrary cancellation remains real for much of the industry. Since states which have only a Financial Responsibility Law to govern cancellation of automobile liability policies appear to be in the majority, ${ }^{35}$ it is fair to conclude that absent legislation, most of the states offer little or no protection against arbitrary cancellations.

"1 The extreme difference in bargaining power between insurance companies and individuals suggests that in a particularly distressing case, equitable concepts of unconscionability might be used to attack the enforcement of the cancellation clause. Professor Corbin suggests that "[t]here is sufficient flexibility in the concepts of fraud, duress, misrepresentation, and undue influence, not to mention differences in economic bargaining power, to enable the courts to avoid enforcement of a bargain that is shown to be unconscionable . . ." I A. Corbin, Contracts $\$ 128$ (1963). See Williams v. Walker-Thomas Furniture Co., 350 F.2d 445 (D.C. Cir. 1965); Steven v. Fidelity \& Cas. Co., 58 Cal. 2d 862, 377 P.2d 284 (1962).

The approach taken by courts in mitigation of the rigors of cancellation suggests that an unconscionability attack in a proper case might be well received. See notes 39-44 infra and accompanying text. However, since such cancellation clauses are not forbidden by law, see. e.g. N.C. GEN. STAT. \$20-310 (Supp. 1967), it would seem that the degree of unconscionability would have to be egregious to stimulate court action. In addition, the recent trend toward enactment of legislation regulating cancellation, see infra, would seem to indicate that legislatures recognize that cancellation clauses are necessary elements of insurance coverage and that the particular means of regulating the use of such clauses is a subject better suited for legislation than the exercise of the equity powers of courts,

zz See, e.g., Trans-America Ins. Co. v. Wilson, 262 Ala. 532, 80 So. 2d 253 (1955); Griffin v. Gen. Accident Fire \& Life Assurance Co., 94 Ohio App. 403, 116 N.E.2d 41 (1953); Allied Concord Financial Corp. v. Sterling Ins. Co., S.C. , 159 S.E.2d 919 (1968); Anchor Cas. Co. v. Crisp, 346 S.W.2d 364 (Tex. Civ. App. 1961); Buffalo Ins. Co. v. Best, 312 S.W.2d 270 (Tex. Civ. App. 1958); Diamond T Utah, Inc. v. Canal ins. Co., 12 Utah 2d 37, 361 P.2d 665 (1961).

I This is perhaps not a nugatory protection. See note 34 infra and accompanying text.

${ }^{*}$ Hearings, supra note 4, at $93,103,112,117,123$.

$\approx$ See note 22 supra. 


\section{Statutes Offering Procedural Protection}

A number of states have provisions in addition to and separate from their Financial Responsibility Law which govern the cancellation of automobile liability insurance policies. ${ }^{36}$ This type of statute generally provides that the insurer may not cancel without mailing or delivering notice to the insured of its intent to cancel. The notice, in a prescribed form, must be sent a certain period of time in advance of the effective date of cancellation contained in the notice. ${ }^{37}$ Statutes of this type do not affect the ability of the insurer to cancel, but only prescribe the procedure which must be followed in order to effectuate cancellation. As is the case where no statute at all or only a Financial Responsibility Law is applicable, these "procedural" statutes offer very little protection against arbitrary cancellation, since advance notice of an arbitrary cancellation does not seem to change its character. Although arbitrary cancellation is still possible under "procedural" statutes, it must be noted that these statutes have been enacted only for the limited purpose of enabling the cancelled policyholdcr to receive sufficient notice of the impending cancellation in order to obtain other liability insurance and avoid a gap in coverage. ${ }^{38}$

However, judicial construction of the procedural statutes may provide some degree of protection to the insured beyond the bare noticc of cancellation. Since such statutes are construed to accomplish the legislature's purpose of providing some warning, ${ }^{39}$ insurers will be required to comply strictly with the procedures

${ }^{36}$ See. e.g.. Fla. STAT. ANN. \$ 324.181 (1968) (included within the Financial Responsibility Law); Iowa Code $\S 515.8$ I (Supp. 1969); LA. Rev. Stat. ANN. \$ 22:636 (1959) (Louisiana enacted a much more restrictive statute in 1968. See LA. REv. STAT. ANN. \$ 22:636.1 (Supp. 1969)); ME. Rev. Stat. ANN. tit. 24, § 1051 (1964); Md. ANN. Code art. 48A, $\$ 240 A$, 240B (1957); MICH. StAT. ANN. $\$ 24.13020$ (1957) (Michigan also has a more restrictive statute in addition to the notice statute. See MICH. STAT. ANN. $\$ 24.13220$ (Supp. 1969)); N.D. CiNT. CODE $\$ 26-02-33$ (Supp. 1967); VA. Col) ANN. \$ 38.1-70.9 (Supp. 1968).

I See, e.g., lowa CODE $\$ 515.8$ I (Supp. 1969); VA. CODE ANN. \$ 38.1-70.9 (Supp. 1968).

s See Am. Fidelity \& Cas. Co. v. Knox, 164 F. Supp. 3 (W.D. La. 1958); Levinson v. Travelers Indem. Co., 258 N.C. 672, 129 S.E.2d 297 (1963). See also Merrimack Mut. Fire Ins. Co. v. Scott, 219 Ark. 159, 240 S.IV.2d 666 (1951); Cantrell v. Benefit Ass'n of Ry. Employees, 136 Mont. 426, 348 P.2d 345 (1959); Poch v. Equitable Life Assurance Soc'y, 343 Pa. 119, 22 A.2d 590 (1941); State Auto Mut. Ins. Co. v. Lloyd, 54 Tenn. App. 587, 607, 393 S.W.2d 17, 26 (1965); Buffalo Ins. Co. v. Best, 312 S.IV.2d 270 (Tex. Civ. App. 1958).

Id. 
contained therein. ${ }^{40}$ Such compliance is required even though the insured may have received notice which comports with the basic purpose of the statute and which, in fact, was sufficient to inform him that his insurance was being cancelled. Other "procedural" matters, such as whether actual receipt of notice of cancellation ${ }^{42}$ or tender of unearned premiums ${ }^{43}$ are required to effectuate cancellation, may also be used to extend the protection of the statute. Should such requirements result from judicial construction, usual canons of insurance contract interpretation would apply, and the insurer would be required to follow the same procedure for future cancellations of similar contracts. ${ }^{44}$ However, it seems that insurers can meet any new requirements that result from judicial construction by redrafting their contracts, and will continue to be able to cancel other policies in the future with little difficulty.

The significance of a protective judicial construction is much greater for an individual litigant since the insurer is forced to indemnify the insured as a result of the decision. The value of such a construction may be observed in Selken $v$. Northland Insurance

to See, e.g., Clark v. Employers Mut. Cas. Co., 90 F.2d 667 (8th Cir. 1937); Sanks v. St. Paul Fire \& Marine Ins. Co., 131 Neb. 266, 267 N.W. 454 (1936) (see also NEB. REV. STAT. $\S$ 44-379 (1960)); Virginia Farm Bureau Mut. Ins. Co. v. Saccio, 204 Va. 769, 133 S.E.2d 268 (1963). See also Lewis Mach. Co. v. Aztec Lines, 172 F.2d 746 (7th Cir. 1949) (Interstate Commerce Act, 15 U.S.C. $\$ 315$ (1964)); Trans-America Ins. Co. v. Wilson, 262 Ala. 532, 80 So. 2d 253 (1955) (policy provisions).

"Crisp v. State Farm Mut. Auto. Ins. Co., 256 N.C. 408, 124 S.E.2d 149 (1962). In Perkins v. Am. Mut. Fire Ins. Co., 274 N.C. 134, 161 S.E.2d 536 (1968), the insured had not had the opportunity to read the notice, which seemingly would not have changed the result since thc notice did not accord with the statutory requirements. In other cases, involving policy terms rather than statutes, similar results have obtained despite facts which at least raise a suspicion that the insured actually knew of the cancellation. E.g., Traders \& Gen. Ins. Co. v. Champ, 225 F.2d 802 (9th Cir. 1955), cert. denied, 350 U.S. 958 (1956); Burnett v. Illinois Agricultural Mut. Ins. Co., 318 IIl. App. 629, 48 N.E.2d 559 (1943).

12 See, e.g.. DeHaan v. Marvin, 331 Mich. 231, 49 N.W.2d 148 (195I); Galkin v. Lincoln Mut. Cas. Co., 279 Mich. 327, 272 N.W. 694 (1937). See also Farmers Ins. Exch. v. Taylor, 193 F.2d 756, 759 (10th Cir. 1952). See generally Annot., 64 A.L.R.2d 982 (1959).

${ }^{4}$ See. e.g.. Riverside Ins. Co. v. Parker, 237 Ark. 594, 375 S.W.2d 225 (1964); Ellzey v. Hardware Mut. Ins. Co., 40 So. 2d 24 (La. App. 1949); Barr ex rel Senft v. Country Mut. Cas. Co., 345 IIl. App. 199, 102 N.E.2d 656 (1951). See generally Annot., I27 A.L.R. 1341 (1940).

* For expressions of such canons of construction, see, e.g., Wright v. Columbia Cas. Co., 137 F. Supp. 775 (S.D. W. Va.), affd, 235 F.2d 462 (4th Cir. 1956); Trans-America Ins. Co. v. Wilson, 262 Ala. 532, 80 So. 2d 253 (1955); Farmers Mut. Hail Ins. Co. v. Minton, 279 S.W.2d 523 (Mo. App. 1955) (insurer recovered assessment despite efforts by insured to cancel policy). 
Co. ${ }^{45}$ where the Iowa Supreme Court dealt with the statute governing the cancellation of insurance policies "other than life," which stated that " $[t]$ he policy may be cancelled by the insurance company by giving five days notice of such cancellation . . . .', In accordance with the policy provision, the insurer had mailed a ten day notice to the insured at his home town address, but the insured lived and worked in another town and apparently never received the notice. The Iowa court interpreted "giving" as meaning "to deliver to another" and found a legislative intent that actual receipt of notice by the insured was required to effectuate cancellation, despite the fact that any such intent seemed absent from the face of the statute and no legislative history or other authority was cited in support of the finding. ${ }^{47}$ Similar results have beell reached under other state statutes where notice was not received because the insured lived at a different address than that shown in the policy. ${ }^{48}$ In one case, the insurer's agent's knowledge of a changed address was automatically imputed to the insurer without consideration of the particular facts of the agency relationship or of usual agency principles commonly required for imputing an agent's knowledge to the principal..$^{49}$ Such decisions, while defensible under the facts and statutes involved, may represent a judicial feeling that the "procedural" statutes offer inadequate protection against arbitrary cancellation and hence must be construed in a fashion most favorable to the insured party in order to protect both the insured and potential victims of traffic accidents who might sue the cancelled party.

\section{Statutes Governing Ability to Cancel-Initial Attempts}

Statutes of a second group designed to restrict the ability of insurers to cancel not only provide procedures which the insurer must follow, but also estabiish the exclusive reasons for which the

\footnotetext{
45 249 Iowa 1046, 90 N.W.2d 29 (1958).

16 Lowa Cove $\$ 515.81$ (1949).

17249 lowa at 1053,90 N.W.2d at 33.

tx See, e.g.. Skipper v. Fed. Ins. Co., 238 La. 779, 116 So. 2d 520 (1959); Breitenbach v. Green, 186 So. 2d 712 (La. App. 1966). See also Merrimack Mut. Fire Ins. Co. v. Scott, 219 Ark. 159, 240 S.W.2d 666 (1951); Griffin v. Gen. Accident Fire \& Life Assurance Co., 94 Ohio App. 403, 116 N.E.2d 41 (1953).

"Skipper v. Fed. Ins. Co., 238 La. 779, 116 So. 2d 520 (1959).
} 
insurer may cancel. ${ }^{50}$ These statutes (hereinafter referred to as Group 11 statutes) typically provide that before an insurer may cancel a policy which has been in effect for more than sixty days, a prescribed form of notice must be given to the insured and to the Department of Motor Vehicles at least fifteen days in advance of the effective date of cancellation. Furthermore, the notice must specify the statutorily authorized reason for which the insurer is cancelling.51 Generally, Group II statutes restrict the reasons for cancellation to: non-payment of premium by the insured; violation of any term or condition of the policy by the insured; revocation or suspension of the driver's license of the insured or any other 'customary operator of the insured vehicle; development of a tendency to heart attacks or epilepsy by the insured; and conviction of the insured for certain specified offenses..$^{52}$

Some Group II statutes attempt to avoid the highly litigated areas of receipt of notice and tender of unearned premiums as prerequisities to cancellation by providing that mailing of the notice by registered mail is sufficient proof of notice $e^{53}$ and that tender of unearned premiums may be made after cancellation.5 While these requirements have been utilized to mitigate the hardships of cancellation, ${ }^{55}$ the enactment of exclusive, specified reasons for cancellation arguably renders such judicial devices unnecessary.

However, assuming protection of the insured to be the purpose

\footnotetext{
50 Fla. Stat. ANn. $\$ 627.0852$ (Supp. 1969); Ga. Code ANN. $\$ 56-2430$ (Supp. 1968); Ill. ANN. Stat. ch. 73, § 755 (Smith-Hurd Supp. 1969); Kan. Stat. ANN. \$ 40-276 to 281 (Supp. 1968); Мich. Stat. ANN. $\S 24.13220-60$ (Supp. 1969); MinN. Stat. ANN. $\S 72 A .141-148$ (1968); N.C. GEN. STAT. $\$ 20-309$ to 310 (1965); S.C. Code ANN. § 46750.51 (1968); WASH. Rev. CODE ANN. $\$ 48.18 .294$ (Supp. 1968). Massachusetts is arbitrarily inserted at this point as the statute defies characterization under the scheme of this comment. MASS. GEN. LAwS ANN. ch. 175, § 113A (1959). It seems to be basically a notice statute but there is an elaborate administrative appeal structure available to the insured who may appeal on the grounds that the cancellation was invalid or improper and unreasonable or both, ch. $175, \S 113 \mathrm{D}$.

31 E.g., Mich. Stat. ANn. $\S 24.13224$ (3) (Supp. 1969); N.C. Gen. Stat. $\$ 20-309$ (e), 310 (1965).

32 E.g., lil. Ann. Stat. ch. 73, §755.3 (Smith-Hurd Supp. 1969); Kan. Stat. ANN. $\S 40$. 277 (Supp. 1968); N.C. GEN. STAT. \& 20-310(b) (1965).

${ }^{3}$ Ill. ANn. Stat. ch. 73, $\$ 755.6$ (Smith-Hurd Supp. 1969); Minn. Stat. ANn. $\S 72 A .145$ (1968); N.C. GEN. STAT. \& 20-310(a) (1965).

${ }^{34}$ GA. CODE ANN. $\S 56-2430$ (Supp. 1968). If such issues are not dealt with specifically, it would seem that they retain viability despite enactment of a cancellation statute. See Griffin v. Hartford Accident \& Indem. Co., 264 N.C. 212, 141 S.E.2d 300 (1965).

${ }^{35}$ See notes 45-49 supra and accompanying text.
} 
of the Group 11 statutes, the wide latitude created by the number of permissible reasons for cancellation would seem to interfere with its realization. The reasons for which an insurance policy may be cancelled are broad enough to include any occurrence which could increase the risk to the insurer as well as some which seem unrelated to any such change..$^{56}$ Thus, the insured may be less adequately protected under Group II statutes since the insurer retains the ability to cancel for rcasons which may not reflect an increased risk and the traditional judicial tools for mitigating excessively harsh results have been excluded by the statutes.7

Litigation under Group II statutes may indicate that such a reading of these statutes is not implausible. Despite the provisions outlining exclusive, specified reasons for cancellation in Group 11 statutes, there apparently has been no litigation involving the sufficiency of any insurer's reason for cancelling. ${ }^{58}$ Since litigation under these statutes has been exclusively concerned with procedural aspects, there has been limited impact outside of the "procedural" area.59 However, there is an important difference between the Group II and "procedural"' statutes. The statutes which restrict the insurer's ability to cancel to exclusive, specified situations evidence on their face a broader legislative concern than simply providing time for the cancelled party to obtain new insurance. Such a broader legislative purpose could enable a court

\footnotetext{
${ }^{5}$ Several Group II statutes provide that conviction of a felony is a suitable ground for cancellation. E.g., N.C. Gen. Stat. \$ 20-310(b) (1965); Wash. Rev. Code AnN. $\S 48.18 .294$ (Supp. 1968). Yet, there would seem to be nothing inherent in embezzlement, for example, which would render an embezzler an increased risk to the insurer. It is of course possible that felons as a class are much worse risks, in which case the provision is justifiable. Compare MinN. Stat. ANN. § 72A.142 (1968) which lacks any such provision. Insurers maintain that statistical analysis reveals certain occupations such as bartenders, waitresses, and musicians, and other groups such as divorced or separated people present a degree of risk which merits cancellation. Each company has a slightly different group of statistical "bad risks" which change from time to time since the insurers use 625 different factors in their evaluation. Interview with Alexander Popoff, De Frates Insurance Agency, in Philadelphia, Pa., March 29, 1969. The statute does not deal and should not deal with the underlying rcasons in such detail. Assuming that insurers are able to charge a premium which accurately reflects the risk involved, they should not be able to cancel for any variation in the risk but rather should elevate some of these factors into the "term or condition of the policy" rubric if cancellation is in fact mandated by risk figures.

${ }^{57}$ See notes 53-54 supra and accompanying text.

${ }^{3 *}$ At least no cases have been found adjudieating the sufficiency of an asserted statutory reason for cancellation.

Sce notes $45-49$ supra and accompanying text.
} 
which applies a Group II statute to do so with a less constricted approach than is the case with the limited purpose "procedural" statute, even though the issues involved in litigation tend to be similar under both types of statute. ${ }^{60}$ One Group II statute, in effect in North Carolina, requires that the cancellation notice contain a "statement that financial responsibility is required to be maintained continously throughout the registration period and that operation of a motor vehicle without maintaining such financial responsibility is a misdemeanor ...." Although there could be little doubt that a cancellation notice lacking such a statement would still apprise the insured of the status of his policy, the North Carolina Supreme Court has held that lack of such statement renders cancellation ineffective. ${ }^{62}$ The court stated that the legislature intended the required notice to be a "firm reminder ... of the law" and hence such notice was not a mere formality ${ }^{63}$ The same court, construing the same statute in a different factual situation, adopted a still broader protective interpretation. ${ }^{64}$ In this case, the insurer had attempted to cancel a non-certified assigned risk policy, giving fifteen days notice to the insured, apparently in reliance on statutory language to the effect that the cancellation provisions were not applicable to assigned risk policies. Despite such language, the court reasoned that the legislature could not have intended to grant insurers a broader right to cancel assigned risk policies than other policies. ${ }^{65}$ Noting that an earlier Financial Responsibility Law was incorporated by reference into the later act, ${ }^{66}$ the court applied the cancellation provisions of the earlier enacted law, and since these provided strict requirements for cancellation of a certified assigned risk policy, the cancellation of the non-certified policy was also held ineffective. ${ }^{67}$ Absent the presence of the general

\footnotetext{
${ }^{\circ}$ Compare Harrelson v. State Farm Mut. Auto. Ins. Co., 272 N.C. 603, 158 S.E.2d 812 (1968) with Breitenbach v. Green, 186 So. 2d 712 (La. App. 1966).

"N.C. Gen. Stat. § 20-310(a) (1965).

${ }^{62}$ Crisp v. State Farm Mut. Auto. 1ns. Co., 256 N.C. 408, 124 S.E.2d 149 (1962).

os Id. at 414,124 S.E.2d at 154.

"4 Harrelson v. State Farm Mut. Auto. Ins. Co., 272 N.C. 603, 158 S.E.2d 812 (1968).

${ }^{65} I d$. at 611,158 S.E.2d at 818 .

"Id. at 610,158 S.E.2d at 818 .

of Id. at 612,158 S.E.2d at 819 . Such a broad application of the statute was apparently in response to the problem presented by the facts of the case and the statutory language. It is doubtful that the legislature actually intended non-certified assigned risk policies to be more easily cancelable than other policies, since the non-certified assigned risk policy is issued to
} 
protective intent behind the Group II type statute it is questionable whether the court could have reached this conclusion.

Furthermore, since all the major potential changes in the insurance risk are available under Group 11 type statutes and the troublesome areas of receipt of notice and tender of unearned premium are settled by the statutes in the insurers' favor, ${ }^{68}$ it may be argued that the statutes actually protect not the policyholder but the insurer. Thus, it seems reasonable to conclude that the insurer would not be likely to precipitate a law suit by using an unapproved reason for cancellation. Also, since the statutes generally allow cancellation when there is a change in the insurance risk and since the approved reasons for cancellation are based on facts subject to ready verification, there is no economic incentive for insurers to cancel on other than permissible grounds nor a great possibility for mistake as to the facts. Probably for both of these reasons, there are apparently no cases litigating the sufficiency of asserted grounds for cancellation under Group II statutes. ${ }^{69}$ Since Group 11 statutes generally restrict the available grounds for cancellation to legitimate changes in the insurance risk, ${ }^{70}$ however,

enable the motor vehicle owner to comply with the compulsory insurance requirements of the Vehicle Financial Responsibility Act. N.C. GEN. STAT. $\S \S 20-309$ and 20-314 (1965). Certified assigned risk policies are issued pursuant to the Safety and Responsibility Act, N.C. GEN. STAT. $\S \S 20-279.1$ and 20-279.34 (Supp. 1967) which establishes requirements for certain classes of drivers. See note 24 supra and accompanying text.

The legislature, however, did not deal specifically with non-certified assigned risk policies as it had with certified assigned risks in the earlier statute. Having given specific treatment to the certified assigned risk, the legislature's failure to treat specifically the non-certified assigned risk arguably demonstrated a legislative intent for a lesser degree of protection for non-certified policies. Such an interpretation, however runs counter to the policy behind assigned risk plans of enabling drivers to obtain and keep liability insurance in order to protect the public from insolvent high risk drivers when insurers would not ordinarily insure. See N.C. Gen. Stat. \$ 20-279.34 (Supp. 1967); Jones v. State Farm Mut. Auto. Ins. Co., 270 N.C. 454,460 , 155 S.E.2d II8, 123 (1967). Thus, on balance, the problem with the noncertified assigned risk appears to have arisen from legislative inadvertence rather than by design. The court did not advert to any such analysis, however, and shied away from the logical implication of its holding by noting that it refused to decide whether non-certified assigned risks became in legal effect the same as certified assigned risks. Yet, from the reasoning employed and the result obtained, the court in effect determined that at least for the purpose of cancellation the two will be treated identically.

ox See notes 52-55 supra and accompanying text.

"Some explanation of this phenomenon must be attempted despite the number of competing inferences which may be drawn from the absence of cases. For a more realistic explanation sec note 82 infra and accompanying text.

${ }^{70}$ See notes 52-55 supra and accompanying text. 
they do effectively proscribe purely arbitrary cancellations. Furthermore, the inference that Group 11 statutes have been effective in preventing arbitrary cancellations, without being burdensome to insurers, seems to have support beyond the mere absence of cases litigating sufficiency of reasons for cancellation. The major mutual and stock companies had experience with this type of statute prior to their 1962 decision $^{71}$ to limit their cancellations to those reasons specified in Group II statutes..$^{72}$ Arguably, this experience convinced the insurers that the statutes benefited the public while not unduly prejudicing their own financial operations. These same companies not only adopted such restrictions themselves, but also pressed other state legislatures to enact them into law. ${ }^{73}$

\section{Statutes Governing Ability to Cancel-Latest Efforts}

Although the notice and Group 11 statutes have provided some improvements the problems of cancellation apparently remained in 1968 when the major insurance companies further voluntarily restricted their cancellations to two situations: where the insured has his driver's license suspended or revoked by the state, and where the insured has failed to pay the premium due on the contract. ${ }^{74}$ Again, the insurers have urged legislative adoption of these standards by all states. ${ }^{75}$ Although it is still too early to determine whether there is a trend toward such restrictive legislation, several important jurisdictions have adopted statutes similar to the recommended one. ${ }^{76}$ The statutes (hereinafter referred to as Group

" E.g., N.C. Gen. Stat. $§ 20-310$ (1965) (enacted by ch. 1393, $§ 2$, [1957], Session Laws of North Carolina 1586).

12 Hearings, supra note 4, at 103,112,117, 123. The insurers who took this voluntary step were the major insurance writers such as Aetna Life \& Casualty Co. and the approximately 130 other members of the Insurance Rating Board and the Mutual Insuranee Rating Bureau. Letter from Mr. Robert W. Rahn, Division Research Attorney, Underwriting Research \& Development Division, Aetna Life \& Casualty Co. to Duke Law Journal, Mar. 13, 1969.

73 Hearings, supra note 4, at 93-94, 103, 118; Letter from Bob Moretti (Assemblyman, California Legislature) to the Duke Law Journal, Nov. 7, 1968 ("progressive" insurers supported CAL. INS. CODE $§ 661$ (West Supp. 1968)).

"Hearings, supra note 4, at 103, 112, 117, 123.

7s Id.; Letter from Bob Moretti (Assemblyman, California Legislature) to the Duke Law Journal, Nov. 7, 1.968.

"CAL. INs. Code $\S \S 660-69$ (West Supp. 1968); La. Rev. Stat. ANn. $§ 22: 636.1$ (Supp. 1969); N.J. Stat. ANN. $\S 17: 29$ C-1 to 29C-13 (Supp. 1968); N.Y. INS. LAW § 167a (McKinney Supp. 1968); PA. Stat. ANN. tit. $40 \S \S 1008.1-.11$ (1969). 
III statutes) are quite similar, most requiring twenty days notice of any proposed non-renewal or cancellation on the two permissible grounds. ${ }^{77}$ The major difference among the statutes appears to be the treatment accorded policy coverages other than liability, such as theft or collision. California and New Jersey allow the insurer to modify the policy only to the extent of inserting a one hundred dollar deductible feature without having to fulfill the statutory requirements for a cancellation. ${ }^{78}$ New York, in contrast, apparently allows the insurer to make major modifications of the policy even to the extent of cancelling these other coverages without complying with the statutory requirements for grounds of cancellation ${ }^{79}$ It is interesting to note that the insurers supported the California position, ${ }^{80}$ which seems on its face to be more clearly concerned with the welfare of the insured than is the New York statute.81

It will be some time before the first cases arise under these statutes, but certain elements of such cases should follow predictable lines. Primarily, and very likely exclusively, the cases will involve the procedural aspects of the statutes rather than the substantive reasons available for cancellation. The approved grounds for cancellation under these statutes are definite, and if there has been no litigation involving the more complex reasons in

$\pi$ CAL. INS. Code $\S 662$ (West Supp. 1968); LA. Rev. Stat. ANn. § 22:636.lc (Supp. 1969); N.J. Stat. ANN. § 17:29C-8 (Supp. 1968); N.Y. INs. LAw $\S 167 a 3$ (MçKinney Supp. 1968). Pennsylvania requires thirty days notice. PA. Stat. ANN. tit. 40, $\S 1008.5$ (Supp. 1969). New York requires forty-five days notice of intention not to renew. N.Y. INs. LAw $\S 167 a 4$ (McKinney Supp. 1968).

${ }^{7 x}$ Cal. INS. Code $\S 661$ (c) (West Supp. 1968); N.J. Stat. ANN. $\S$ 17:29C-7(C) (Supp. 1968).

" N.Y. INS. LAw § $167 a 3$ (McKinney Supp. 1968). Louisiana and Pennsylvania hàve no such exception in their statutes. See note 77 supra.

${ }^{\text {so }}$ See notes 73 and 74 supra and accompanying text. Insurers support such legislation in spite of the fact that arbitrary cancellations have not occurred in substantial numbers. They feel that the statutes are in the public interest and protect the competitive position of the insurers by binding all insurance companies. In addition, some insurers are concerned with any practice which adversely affects the reputation of the industry. Letter from Mr. Robert W. Rahn, Division Research Attorney, Underwriting Research \& Development Division, Aetna Life \& Casualty Co. to the Duke Law Journal, Mar. 13, 1969.

${ }^{81}$ The New York statute appears to be more concerned with the liability insurance portion of a comprehensive liability policy. Thus, it seems that the strongest motive behind the statute is not consumer protection, as Governor Rockefeller has stated, see 1968 MCKINNEY's SEsSion LAW News A-190, but rather the more traditional one of protecting the solvency of prospective defendants. 
the Group II statutes, then these Group III statutes should virtually foreclose the prospect of such litigation.

Where the clarity and succinctness of the reasons for cancellation under Group III statutes will tend to discourage litigation on the sufficiency of an asserted ground, there is a more realistic explanation for the predictable absence of litigated cases. Both Group II and Group III statutes are applicable only to policies which have been in effect for more than.sixty days. ${ }^{82}$ Thus during the first sixty days of a policy, the insurer may cancel for any reason it deems adequate or for no reason at all. This feature of the statutes seems to result from the fact that insurance is sold in response to public demand rather than to a conscious marketing decision on the part of insurers. ${ }^{83}$ Generally, new, as opposed to renewal, contracts of automobile liability insurance are concluded in connection with the purchase of an automobile. The buyer with any knowledge of liability hazards is required by common sense, or in some cases by state law, ${ }^{84}$ to buy liability insurance before driving his new car. In response to the resultant demand for rapid coverage, insurers provide coverage for the driver from the time that the insurance application is completed and the initial premium paid. The insurer must then investigate the application while facing the chance of loss on a possibly unprofitable risk contract. ${ }^{85}$ The sixty-day limitation before the statutes become applicable may be read as a legislative concession to the industry's marketing practice which, however, is regulated by a reasonable time limit.

Under Group III statutes there is a stronger argument to support such a time limit than is available under Group II statutes. Under Group 111 statutes, the insurer may cancel for two reasons only after the sixty-day period, and it seems fair to allow the insurer the opportunity to investigate and reject the high risk drivers before the insurer is irrevocably bound. Under Group II statutes, however, the reasons available for cancellation during the

\footnotetext{
s2 Compare N.C. Gen. Stat. $\S 20-310$ (1965) with CAL. INs. Code $\$ 661$ (b) (West Supp. 1968).

$\approx$ See Jensen v. Traders \& Gen. Ins. Co., 52 Cal. 2d 786, 798, 345 P.2d 1, 7 (1959).

\& Mass. Gen. Laws ANN. ch. 175, §§ 113A-113L (Supp. 1968); N.Y. VeH. \& TRAF. Law $\S \S 310$-2I (McKinney 1960); N.C. GEN. STAT. § 20-309 (1965).

\& E.g., Del. Code ANn. tit. 21, § 2904(1)(1) (1953); Hawall Rev, Laws \$160-107(a) (1955); lowa CODE § 321A.21(6)(a) (1966); N.C. Gen. Stat. § 20-279.21(f)(1) (Supp. 1967).
} 
entire term of the policy seem broad enough to include any legitimate change in the insurance risk revealed by the insurer's investigation. Thus, the Group II statutes do not seem to be so restrictive as to provide sufficient justification for delaying the applicability of the cancellation statute.

Once the sixty-day period has passed and the cancellation statute is applicable, non-renewal of the policy becomes the major area of potential arbitrary action. There is some indication that insurers have shifted away from cancellation to non-renewals as the major method of weeding out unacceptable risks. ${ }^{86}$ Unfortunately, neither Group II nor Group III statutes address themselves to the substantive issues involved in non-renewals. Generally, all that is necessary to accomplish a non-renewal under either type of statute is to provide the insured party with a certain period of advance notice that the insurer intends not to renew the policy, that the reasons for which the action is being taken will be supplied upon request, that the insured may make such a request within a certain period after the effective date of the notice and that the assigned risk plan is available. ${ }^{87}$ It seems obvious from the language of the statutes that the insurer could choose not to renew for any reason it deemed sufficient. However, as is the case with the sixty-day cancellation period, the non-renewal device should not receive blanket condemnation. The experience during the past few years of a large number of high risk insurance carriers becoming insolven $t^{88}$ points out the danger of requiring a company to insure large numbers of high risk drivers. These drivers have available to them the assigned risk plans which are part of Financial Responsibility Laws enacted in virtually all states, ${ }^{89}$ if the insurer fails to renew their policy. The assigned risk plans theoretically allocate the high risk drivers equitably among the insurers and avoid concentrating such risks in any single company..$^{90}$

* Crisis in Car Insurance 264 (R. Keeton, J. O'Connell \& J. McCord, ed. 1968).

* E.g., Cal. INs. COde $§ 663$ (West Supp. 1968); N.C. Gen. Stat. $\S 20-310(c)$ (1965).

"Hearings, supra note 4, at 12,15,37, 72; CRISIS IN CAR INSURANCE 255 (R. Keeton, J. O'Connell \& J. McCord, ed. 1968).

${ }^{* 3}$ For a complete listing of Financial Responsibility Laws, see Loiseaux, Innocent Victims 1959, 38 TEx. L. Rev. 154, 157 (1959). See generally Legislation, A Survey of Financial Responsibility Laws and Compensation of Traffic Victims: A Proposal for Reform, 21 VAND. L. REv. 1058 (1968).

0 E.g., N.C. Gen. Stat. \$ 20-279.34 (Supp. 1967). See also Jones v. State Farm Mut. Auto. Ins. Co., 270 N.C. 454,155 S.E.2d II8 (1967). 
On the basis of the foregoing analysis, it appears that the sixtyday waiting period before cancellation statutes become applicable and the non-renewal device are the major opportunities for 'arbitrary action by insurers under either Group II or Group III statutes. Assuming that the fault liability system will continue $e^{01}$ and that it is desirable to restrict the insurers' ability to cancel policies in order to ensure that the largest possible number of drivers are covered by liability insurance, it would seem that any statute which attempts to restrict cancellations must address not only the substantive reasons for cancellation, as in the Group II and Group III statutes, but also must deal with the sixty-day time limit and with non-renewals.

Several alternative approaches may be suggested. First, it would seem possible to dispense with the sixty-day time period or any shorter period and retain the limited cancellation provisions of either Group II or Group III statutes. This would have the effect of requiring the insurer as a practical matter to investigate the applicant before issuing a policy, particularly in Group III statute cases. However, it would seem that such a solution would run afoul of the public demand for rapid insurance coverage and would probably be unacceptable for that reason. As to Group 11 statutes, though, the situation is somewhat different. As noted earlier, those statutes seem to contain all legitimate changes in the risk to the insurer as grounds for cancellation. ${ }^{92}$ Thus, if the time period before the statute becomes applicable were removed, all arbitrary cancellations would be proscribed, yet the insurer could still investigate and cancel the policy in the event the actual risk was not correctly represented in the policy application. ${ }^{93}$ The fact that the insurer would bear the risk of loss would provide adequate incentive for an early resolution of the investigatory efforts, probably within the present sixty-day time limit. Thus, it would seem that as to Group II statutes, the sixty-day time period is not only a major loophole for potential misuse by insurers, but is also superfluous, so far as the economic needs of insurers are concerned.

\footnotetext{
" For the most publicized alternative suggestion, see R. KeEton \&. J. O'ConNell, BAsic Protection for the Traffic Victim (1965).

12 See notes 52-55 supra and accompanying text.

n E.g., N.C. GEN. STAT. $\S 20-310$ (b) (2) (1965) provides as a ground for cancellation the fact that "[t]he insured violates any of the terms and conditions of the policy . . . " Fraud
} 
A second alternative approach would be to dispense with the sixty-day period, require the insurer to carry everyone whose application is accepted initially, but allow the insurer to refuse to renew. However, the insurer would again be forced to investigate the risk in advance of coverage or be subject to substantial financial loss, and that approach is thus subject to the same weakness noted above. In addition, such a plan would be unduly restrictive on the insurer since the insurance risk of any particular driver may change and become so great that the insurer should be able to cancel. Of course, Group 111 statutes are to some degree also subject to this criticism.

A third approach to the sixty-day time period would be to dispense with the period, forbid cancellations, but allow the insurer to charge a premium commensurate with the true insurance risk as soon as investigation reveals that the risk is not correctly represented in the application. Should the insured be unwilling to pay the higher premium, he would have the option of cancelling the policy himself or of being transferred to the assigned risk plan. As additional protection against a gap in coverage, the insurer in this circumstance could be required to bear the risk until the risk was assigned by the state authority. Under this approach, the insurer could investigate at his leisure, under the incentive of bearing the risk of loss, yet could avoid high risk losses by charging a premium appropriate to the risk. ${ }^{94}$

The approach to the problem of non-renewal depends largely on the manner in which the sixty-day period is handled and must also be addressed if the goal of preventing arbitrary action is to be accomplished. At a minimum, any statute attempting to solve the problem should proscribe non-renewals which are not based on a significant change in the risk created by the insured. Whether this should be accomplished by a statute in general terms or by a specific list of approved reasons for non-renewal must be a legislative decision, but some observations may be offered as to that decision. If the statute is a Group II statute, listing all the

or mistake in the application for the policy should be clearly included in such language or would quickly become included by appropriate policy language.

H This assumes that the insurer would be permitted to set a premium which accurately reflected the risk involved rather than have a state agency control the premium except for the assigned risk. 
legitimate changes in the insurance risk as grounds for cancellation, then restricting the insurer to those reasons for non-renewals as well would seem neither overly restrictive nor harsh, since the functions of cancellation and non-renewal are essentially identical. Group III statutes present a different problem since the available reasons for cancellation are greatly limited. Were insurers restricted to those reasons for non-renewal as well as for cancellation, it would be possible for a group of once insured high risk drivers who pay their premiums and manage to avoid having their driver's licenses suspended or revoked to become concentrated in a few companies. In order to avoid such a possibility, the insurer under Group III statutes should be allowed somewhat greater latitude in refusing to renew than is presently available in cancellation. ${ }^{65}$ Perhaps an alternative could be to forbid non-renewal except for Group III statutory grounds, but to permit the insurer to increase premiums commensurate with the risk up to the assigned risk rate.

Other suggestions may be propounded to close the loopholes in the statutes that result from the sixty-day period and the unrestricted ability to refuse to renew. ${ }^{96}$ However, it would seem that the fairest method suggested among those noted above would be a modified Group II statute. Limiting cancellations to a complete list of potential changes in the insurance risk without waiting sixty days for the statute to apply seems neither harsh nor inequitable. Furthermore, limiting the substantive grounds for non-

\footnotetext{
s5 It is pure speculation, but perhaps true, that insurers support Group III statutes on the tacit understanding that the unrestricted non-renewal and the sixty day "grace period" for the insurer will remain in the statute. It seems unlikely that insurers would support such restrictions on non-renewal as well as cancellation.

* Methods of enforcing cancellation statutes follow one of two variations. The traditional approach seems to be a suit by the cancelled policyholder against the insurer after a judgment has been entered against the insured in a separate action. The second pattern, exemplified by Massachusetts, is to provide some administrative structure to determine the validity of cancellations after an appeal by the insured.

The traditional approach leaves the policyholder in a difficult position. He must win in a suit against the insurer or be faced with satisfying a judgment. See N.C. GEN. STAT. § 20310 (1965) (no enforcement procedure); Perkins v. Am. Mut. Fire Ins. Co., 274 N.C. 134, 16I S.E.2d 536 (1968). While a suit for declaratory judgment offers a possible method of resolving the controversy in advance of any accident and judgment against the insured, the policyholder would still be forced into the courts with the attendant delay, evidentiary difficulties and expense.

Massachusetts, in contrast, provides for an appeal board made up of representatives of the Attorney General, the Insurance Commissioner, and the Registrar of Motor Vehicles. Mass.
} 
renewals to the same reasons as are available for cancellation would seem to be a logical extension of the original protection given against arbitrary cancellation. Such a modified statute would meet the market demand for rapid coverage yet allow the insurer to cancel if the risk changes too greatly or is inaccurately represented in the application, while at the same time precluding arbitrary action. It is also possible that if a sufficient number of states adopt such an approach to cancellations, the actual or apparent need for federal regulation would diminish considerably.

GEN. LAwS ANN. ch. 26, $\S 8$ A (1958). The insured may appeal any refusal to insure or any cancellation to that board and has further recourse to the eourts in the event of an adverse determination. MASS. GEN. LAwS ANN. ch. 175, § 113D (1958). Apparently, the insured has an excellent chance of winning his appeal to the board. See R. KeEton \& J. O'Connell, Basic Protection for the Traffic Victim 78-8I (1965).

A number of the recent statutes appear to follow the Massachusetts example and provide for some administrative determination of the validity of cancellations. E.g., KAN. STAT. AN. $\$ 40-281$ (Supp. 1968); PA. STAT. ANN. tit. 40, $\$ 1008.8,1008.9$ (Supp. 1969). California has taken a different approach by providing that willful violation of the nonrenewal (but not cancellation) provisions of the statute is a misdemeanor punishable by a fine not in excess of five hundred dollars (\$500.00). CAL. INS. CODE $§ 669$ (West Supp. 1968).

In view of the difficult position of the policyholder under the traditional approach and the apparent success of the Massachusetts procedure, it would seem that some variation of that procedure providing an administrative appellate structure to test the validity of caneellations is the best approach for enforcement procedures in any cancellation statute. 
